\title{
緩和された優越性の公理と不確実下の価値関数の構成 一地球温暖化と二酸化炭素排出量規制の評価*
}

\author{
田村 坦之 ${ }^{* *} \cdot$ 北村 浩康 ${ }^{* * *}$-鳩野 逸生 ${ }^{* *}$ - 馬野 元秀 ${ }^{* *}$
}

\author{
On a New Axiom of Dominance and Constructing a Measurable Value Function \\ under Uncertainty \\ -Evaluating Alternative Policies to Decrease Emission of Carbon Dioxide*
}

Hiroyuki Tamura ${ }^{* *}$, Hiroyasu Kitamura***, Itsuo Hatono**

and Motohide UMANo**

\begin{abstract}
In this paper, we revise a previous axiom of dominance for constructing a measurable value function under uncertainty based on Dempster-Shafer theory of probability. The previous axiom of dominance has dealt with only the best and the worst results in the set element. In this paper we propose a new axiom of dominance after defining the value of the set element taking into account the average of the value of all the results included in the set element. We could construct a measurable value function under uncertainty for an ordinary, pessimistic or optimistic person, based on this new axiom of dominance. An example of evaluating the alternatives to regulate $\mathrm{CO}_{2}$ emission for avoiding global warming is included.
\end{abstract}

\section{1.はじめに}

科学技術の発達は人類に多くの福祉をもたらしたが, その反面，科学技術の発達に伴って不特定多数の人間ま たは環境に対して有害な影響を及ぼす危険性も増大して いる．たとえば，経済発展の結果エネルギー多消費を招 き, その結果, 二酸化炭素をはじめとする温室効果ガス による地球温暖化をむたらし, 想像を絶する被害が出る 危険性をはらんでいる，乙のように予想される負の効 果を事前に評価し，それに対する対策を立てるためのシ ステム方法論の確立が望まれる.

人の価值観を定量化して, 経済, マーケティング, 生産 の意思決定のようなリスク下の意思決定に役立てる有用 なモデルとして用いられてきたあのに von NeumannMorgenstrern の期待効用理論 ${ }^{1)}$ がある. 最近の研究に

* 原稿受付 1994 年 3 月 30 日

** 大阪大学 基礎工学部 Faculty of Engineering Science, Osaka University ; 1-3 Machikaneyamacho, Toyonaka city, Osaka 560, JAPAN

*** 大阪大学 大学院 基礎工学研究科 (現在, 松下電工 (秼) Graduate School of Engineering Science, Osaka University ; ditto

Key Words : Dempster-Shafer theory of probability, measurable value functions under risk, axiom of dominance, risk analysis, global warming.
より期待効用理論では説明できない(例2) 4) が数多く報 告されている. ての期待効用理論では説明できない例を 説明する手法に不確実下の価值関数 ${ }^{5)}$ がある. 乙の手法 は, 特殊状況下では期待効用理論を含んで抢り, 確率む 価値観を表現する属性の一つと見なしたモデルである. また，ての手法であ説明できない例6)があり，さらに， Dempster-Shafer の確率理論? 尊入した不確実下の 価值関数による評価法 ${ }^{8)}$ がある. これは, 不確実下の価 值関数の確率部に Dempster-Shafer の確率理論を導 入したあのである.

本論文では, Dempster--Shafer の確率理論を導入し た不確実下の価値関数を構成するにあたって, 複数の焦 点要素の中の最良の結果と最悪の結果のみに注目してい た従来のモデルを，焦点要素に属するすべての要素に注 目して集合の価值判断ができるように新たな優越性の公 理を提案し，乙れに基づいて不確実下の価値関数を構成 するととを試みる．まず，焦点要素に含まれるすべての 要素の価値の平均を考え,

（1）人が焦点要素の価值を判断するとき, 普通の人は 焦点要素に含まれるすべての要素の価値の平均が その焦点要素の価值であると感じる.

（2）悲観的な人は焦点要素の価値がすべての要素の価 
值の平均よりあ低く, 楽観的な人は平均よりも高 く感じる.

ということを仮定する. この仮定のもとで，焦点要素に 含まれる最良の要素と最悪の要素から得られる悲観係数, 最良の要素, 最悪の要素, 平均の四つを用いて, 焦点要 素の価値を決定できるように,「緩和された優越性の公 理」を提案する. ての公理に従って決められる焦点要素 の価値に基づいて不確実下の価值関数を構成し, 代替案 を評価する方法を示す, 最後に, 本論文で提案する新た なモデルを用いて地球温暖化に関わりの深い二酸化炭素 排出量規制に関するいくつかの代替案の評価を試みる.

\section{Dempster-Shafer の確率理論を導入し た不確実下の価值関数 ${ }^{8)}$}

まず, Dempster-Shafer の確率理論を導入した不確 実下の価値関数について簡単に述べる. 不確実下の価值 関数 ${ }^{5)}$ の確率部に基本確率 $\mu^{7)}$ を導入すると,

$$
f^{*}(B, \mu)=w^{\prime}(\mu) v^{*}(B \mid \mu)
$$

となる.乙こで, 可能性のあるすべての要素を含む集合 $\Theta$ の部分集合を焦点要素と呼び，乙れを $B$ と表わし， $\mu$ は $\Lambda=2^{\ominus}$ 上に定義される. $f^{*}(B, \mu)$ は, 基本確率 $\mu$ で得られる焦点要素 $B$ の価值を表わし, $w^{\prime}(\mu)$ は, 基本 確率に対する主観的重み関数, $v^{*}(B \mid \mu)$ は, 基本確率 $\mu$ のもとでの焦点要素 $B$ に関する価値関数を表わす.

このとき, $v^{*}$ の同定は, 集合間の選好関係を規定しな ければならないため困難である. そこで，次のような優 越性の公理を仮定する.

\section{【優越性 (dominance) の公理】}

焦点要素 $B$ に含まれる結果 (要素) のうち, 最悪のも のを $m_{B}$, 最良のむのを $M_{B}$ とすると, $\Lambda$ に含まれる任 意の焦点要素 $B^{\prime}, B^{\prime \prime}$ において,

$$
m_{B^{\prime}} \lesssim m_{B^{\prime \prime}} \text { かつ } M_{B^{\prime}} \lesssim M_{B^{\prime \prime}} \text { ならば } B^{\prime} \lesssim B^{\prime \prime}
$$

補助公理として,

$$
m_{B^{\prime}} \sim m_{B^{\prime \prime}} \text { かつ } M_{B^{\prime}} \sim M_{B^{\prime \prime}} \text { ならば } B^{\prime} \sim B^{\prime \prime}
$$

を得る. ここで, 後者は前者よりあるは好ましいか無 差別を表わす記号， ～は無差別を表わす記号である.

この公理を用いて， $B$ の形式を次のような $\Omega$ に限定 する.

$$
\Omega=\{(m, M) \in \Theta \times \Theta: m \lesssim M\}
$$

この $\Omega$ を用いると（1）式は,

$$
f^{*}(\Omega, \mu)=w^{\prime}(\mu) v^{*}(\Omega \mid \mu)
$$

となる.さらに, $v^{*}$ に, 悲観係数 $\alpha(m, M)$ を導入す ることにより,

$$
\begin{aligned}
v^{*}(\Omega \mid \mu)= & v^{*}(\{(m, M)\} \mid \mu) \\
= & \alpha(m, M) v^{\prime}(m \mid \mu) \\
& +(1-\alpha(m, M)) v^{\prime}(M \mid \mu)
\end{aligned}
$$

で表わされる. 悲観係数は，以下の二つの代替案が，同 程度に好ましいととれるような $\alpha$ を求めることにより决 定する.

（1）最小で $m$, 最大で $M$ を受け取る. そのほかに情 報なし。

（2） $\alpha$ の確率で $m,(1-\alpha)$ の確率で $M$ を受け取る.

$$
\alpha(m, M)=\alpha, \quad 0<\alpha<1
$$

すなわち， $\alpha$ が 1 に近くなるほど悲観的であり，0亿近 いほよ゙楽観的であるといえる。

\section{3. 従来モデルの問題点}

Dempster-Shafer の確率理論を導入した不確実下の 価値関数は，2.で述べたように結果に焦点要素と呼ばれ る集合をとることができる，しかしながら，従来の手法 では集合を評価する場合に, 集合の中の最良の要素と最 悪の要素しか考えていない，集合の要素が二つのときに は問題はないのであるが，集合の要素が三つ以上ある場 合には, 最良の結果, 最悪の結果以外は無視しているて とになる，したがって，意思決定者の実際の選好と従来 モデルで評価した結果が逆になる危険性がある．そのこ とを簡単な例を用いて説明する。

【例 1】 Fig.1 に示すつぼが二つある.つぼ $a$ には黒 玉，黄玉，緑玉が，その割合はわからないが合わせて 30 個入っている，つぼ $b$ には白玉，赤玉，緑玉がその割合 はわからないが合わせて 30 個入っている．意思決定者は $a$ か $b$ よ゙ちらかのつぼから玉を取り出し, 取り出した玉 の色によって次の金額を受けとるものとする.

$$
\begin{aligned}
& \text { 黒……1,000円 白……2,000 円 } \\
& \text { 赤……3, } 000 \text { 円 黄…5 } 5,000 \text { 円 } \\
& \text { 緑…‥6, } 000 \text { 円 }
\end{aligned}
$$

意思決定者がどちらのつぼを選択するかを予想する問題
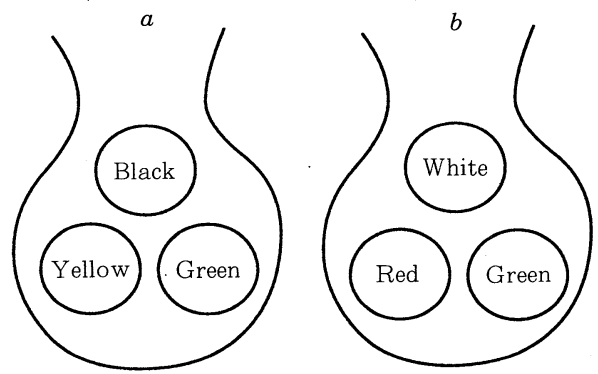

Fig. 1 Urns in Example 1 
を考える。

この場合，結果の集合としては，つぼ $a$ につては 「黒玉を引く」，「黄玉を引く」，「緑玉を引く」から成り， てれらをそれぞれ $a_{1}, a_{2}, a_{3}$ で表わし，つぼ $b$ てついて は「白玉を引く」,「赤玉を引く」,「緑玉を引く」でてれ をそれぞれ $b_{1}, b_{2}, b_{3}$ とする. つぼ $a$ の結果の集合を $B_{1}$, つぼ $b$ の結果の集合を $B_{2}$ とすると,

$$
\begin{aligned}
& B_{1}=\left\{a_{1}, a_{2}, a_{3}\right\} \\
& B_{2}=\left\{b_{1}, b_{2}, b_{3}\right\}
\end{aligned}
$$

となる，そして， $a_{i}, b_{i}(i=1,2,3)$ の価值をそれぞれ $v\left(a_{i}\right), v\left(b_{i}\right)$ とする.

このとき, 優越性の公理に従って価值判断をすると, $a_{1} \lesssim b_{1}$ かつ $a_{3} \lesssim b_{3}$ なので, $B_{1} \lesssim B_{2}$ となる.つまり， どの意思決定者むつぼ $b$ を選択することになる. しかし， たとえば，ある意思決定者がつぼの価值判断を行うにあ たって，その人の受けとり金額が基準になる場合に，つ ぼ $a, b$ の価値は,

$$
\begin{aligned}
& B_{1} \text { の価値 }=\sum_{i=1}^{3} v\left(a_{i}\right)=12000 \\
& B_{2} \text { の価值 }=\sum_{i=1}^{3} v\left(b_{i}\right)=11000
\end{aligned}
$$

となり, $B_{1} z B_{2}$ となり, 優越性の公理によって評価し た結果と矛盾する.

\section{4. 従来の手法の改善}

3. で述べたように, 従来モデルの優越性の公理では不 適切な場合が生じる，そこで，次のように優越性を厳し くする.

\section{【価值の平均を考慮した優越性の公理】}

焦点要素 $B_{1}$ の最悪, 最良の結果をそれぞれ $m_{1}, M_{1}$, $B_{2}$ の最悪, 最良の結果をそれぞれ $m_{2}, M_{2}$ とする. ま た, $B_{1}, B_{2}$ の要素の価值の平均を考え, 価值がその平 均值をとるような架空の要素をそれぞれ $g_{1}, g_{2}$ とする. このとき,

$$
m_{1} \lessgtr m_{2}, \quad M_{1} \lesssim M_{2}, \quad g_{1} \lessgtr g_{2} \text { ならば } B_{1} \lesssim B_{2}
$$

補助公理として, ただし，

$$
m_{1} \sim m_{2}, \quad M_{1} \sim M_{2}, \quad g_{1} \sim g_{2} \text { ならば } B_{1} \sim B_{2}
$$

$v\left(g_{1}\right)=\frac{\sum_{i=1}^{n_{1}} v\left(a_{i}\right)}{n_{1}}, \quad v\left(g_{2}\right)=\frac{\sum_{i=1}^{n_{2}} v\left(b_{i}\right)}{n_{2}}$,

$n_{1}: B_{1}$ に属する要素の個数, $n_{2}: B_{2}$ に属する要素 の個数

とする.

これを仮定した場合例 1 は評価できなくなる.すなわ
ち，受けとり金額がそのままその人の価値判断の基準と なる場合は平均值をとる架空の要素がこの優越性を満た さない.

この優越性を用いた評価の方法を述べる.

この公理を導入して, 最悪, 最良の要素をそれぞれ $m, M$, 平均値をとる架空の要素を $g$ として, $B$ の形式 を

$$
\Omega=\{(m, g, M) \in \Theta \times \Theta \times \Theta: m \lesssim g \lesssim M\}
$$

なる $\Omega$ に限定する.乙のとき，

$$
f^{*}(\Omega, \mu)=w^{\prime}(\mu) v^{*}(\Omega \mid \mu)
$$

と書ける.さらに,

$$
\begin{aligned}
f^{*}(\Omega, \mu)= & f^{*}((m, g, M), \mu) \\
= & \beta_{1} f(m, \mu)+\beta_{2} f(g, \mu) \\
& +\beta_{3} f(M, \mu) \\
& \left(\beta_{1}+\beta_{2}+\beta_{3}=1\right)
\end{aligned}
$$

と書ける.乙こで, $f(m, \mu), f(g, \mu), f(M, \mu)$ は, 各々単一要素に対する価值関数の值を表わしており, 従 来の方法 ${ }^{5)}$ によって求めるてとができる. また, $\beta_{i}(i=$ $1,2,3)$ は各々最悪の結果, 結果の偏り扎よび最良の結 果に対する重みを表わし, 評価者（意思決定者）に質問 して決定する.

この手法を用いて評価した例を次に示す.

【例 2】 Fig. 2 に示すつぼが二つある. つぼ $a$ には黒 玉, 黄玉, 緑玉がその割合はわからないが合わせて 30 個 入っている.つぼ $b$ には白玉，青玉，緑玉がその割合は わからないが合わせて 30 個入っている，意思決定者は $a$ か $b$ どちらかのつぼから玉を取り出し, 取り出した 玉の色によって次の金額を受けとるものとする.

$$
\begin{aligned}
& \text { 黒……1, } 000 \text { 円 白……2, } 000 \text { 円 } \\
& \text { 青……4, } 000 \text { 円 黄…5 5, } 000 \text { 円 } \\
& \text { 緑…‥6, } 000 \text { 円 }
\end{aligned}
$$

意思決定者がどちらのつぼを選択するかを予想する問題 を考える。
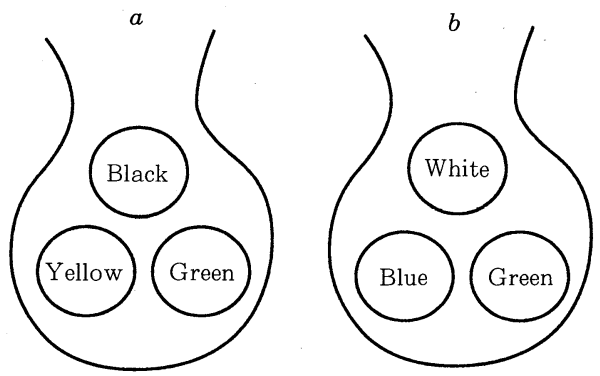

Fig. 2 Urns in Example 2 
例 1 で示したのと同じように考えて

$$
\begin{aligned}
& B_{1}=\left\{a_{1} \text { (黒) }, a_{2} \text { (黄) }, a_{3} \text { (緑) }\right\} \\
& B_{2}=\left\{b_{1} \text { (白) }, b_{2} \text { (青) }, b_{3} \text { (緑) }\right\}
\end{aligned}
$$

とする. 乙の場合, 一般的な人は安全志向で $B_{2}$ を選択 するものと考えられる. このように考える人は価値関数 が上に凸でたとえば，

$$
v(x)=\sqrt{\frac{x-1000}{5000}}
$$

であるとする。このとき，

$$
\begin{array}{lll}
v\left(a_{1}\right)=0, & v\left(a_{2}\right)=0.89, & v\left(a_{3}\right)=1 \\
v\left(b_{1}\right)=0.45, & v\left(b_{2}\right)=0.77, & v\left(b_{3}\right)=1
\end{array}
$$

となり,

$$
\begin{aligned}
& \sum_{i=1}^{3} \frac{v\left(a_{i}\right)}{3}=0.63 \\
& \sum_{i=1}^{3} \frac{v\left(b_{i}\right)}{3}=0.74
\end{aligned}
$$

となる. 乙の場合, 最悪の結果, 最良の結果, 平均值を とるような架空の結果とむ $B_{2}$ の方がよくなり，価値の 平均を考慮した優越性の公理は，一般的な安全志向の人 の価值判断を適切に表現することができる.

\section{5. 優越性の緩和}

制限した優越性は条件が厳しすぎるので優越性を緩め ることを考える：二つの集合間で一方の集合が最良の結 果も最悪の結果もむう一方の集合よりも良い場合でも， 平均についてはもう一方の集合の方が良い場合が考えら れる.乙ういったとき，意思決定者にとってどちらの集 合か好ましいかはその人その人によって異なるであろう。 ある人は最良の結果に重きを扔いてそちらの代替案を選 び，ある人は最悪の結果に重きを掞き，またある人は全 体に注目するであろう．以下に扔いててれらの状況をす べて適切に表現できるモデルを提案する.

\section{【定義】}

焦点要素 $B$ に属する要素を $a_{1}, \cdots, a_{n}$ （ただし， $a_{i} \lesssim ~$ $\left.a_{i+1}, i=1, \cdots, n-1\right)$ とし, 要素 $a_{i}, i=1, \cdots, n$ のそれ ぞれの価值を $v\left(a_{i}\right)$, 要素 $a_{i}$ の価値の平均 $\sum_{i=1}^{n} v\left(a_{i}\right) / n$ を $v(g)$ とおく. さらに, 結果の最悪の要素 $\left(a_{1}=m\right.$ と おく）と最良の要素 $\left(a_{n}=M\right.$ とおく）に対する質問に よって決められる悲観係数を $\alpha(m, M)$ として，焦点 要素 $B$ の価值 $h$ を次のように仮定する.

$v(g) \neq \frac{v(M)+v(m)}{2}$ の時 $h(B \mid \alpha)=a+b e^{-c \alpha(m, M)}$

$v(g)=\frac{v(M)+v(m)}{2}$ の時 $h(B \mid \alpha)=a+b \alpha$
ただし, $h(B \mid 0)=v(M), h(B \mid 0.5)=v(g), h(B \mid 1)=$ $v(m)$ によって未知パラメー夕 $a, b, c$ を決定する. (15a）抽よ゙ (15b) 式は焦点要素 $B$ の価值 $h$ を悲観係 数 $\alpha$ の関数として表現しており, 上に凸，直線，あるい は下に凸となる最も単純な関数として指数関数によって 表現している. gain domain すなわち良くも亜くもない 中立レベル（例えば現状）より好ましい領域においては， $h$ の值が大きくなるほどその選好が強く, loss domain すなわち中立レベルより好ましくない領域においては $h$ の值が小さくなるほど選好が強い. (loss domain の之 きは前にマイナスをつけると, 值の大きい方が選好が強 い.)

この考え方を用いて価值評価できるように次のような 優越性の公理を仮定する.

\section{【緩和された優越性の公理】}

$$
h\left(B_{1} \mid \alpha\right) \leq h\left(B_{2} \mid \alpha\right) \text { ならば } B_{1} \lessgtr B_{2}
$$

補助公理として,

$$
h\left(B_{1} \mid \alpha\right)=h\left(B_{2} \mid \alpha\right) \text { ならば } B_{1} \sim B_{2}
$$

とする.

この緩和された優越性の公理を用いると，不確実下の 価值関数 ${ }^{5)}$ に基本確率を導入したモデルは, 次のように なる。

$$
f^{*}(h(B \mid \alpha), \mu)=w^{\prime}(\mu) h(B \mid \alpha)
$$

また， 2 属性の場合は，

$$
\begin{aligned}
f^{*} & =f^{*}\left(B, x_{2}, \mu\right) \\
& =f^{*}\left(h(B \mid \alpha), x_{2}, \mu\right)
\end{aligned}
$$

さらに，2 属性間に危険選好差独立性 ${ }^{5)}$ を仮定できる場 合には,（17）式は,

$$
f^{*}=f\left(h(B \mid \alpha), x_{2}^{R}, \mu\right)+f\left(h^{R}(B \mid \alpha), x_{2}, \mu\right)
$$

と書ける. ここで, $x_{2}^{R}$ および $h^{R}(B \mid \alpha)$ は，各々 $x_{2}$ お よび $h(B \mid \alpha)$ の中立レベルを表わす.

この新たに提案した緩和された優越性の公理に基づく 手法を用いて例 2 を評価してみる.

まず，悲観的な人の場合を考える．すでに述べたの.と 同じように (12) 式を用いて $v(x)$ を決めると,

$$
\begin{array}{lll}
v\left(a_{1}\right)=0, & v\left(a_{2}\right)=0.89, & v\left(a_{3}\right)=1 \\
v\left(b_{1}\right)=0.45, & v\left(b_{2}\right)=0.77, & v\left(b_{3}\right)=1
\end{array}
$$

となり,

$$
\begin{aligned}
& \sum_{i=1}^{3} \frac{v\left(a_{i}\right)}{3}=0.63 \\
& \sum_{i=1}^{3} \frac{v\left(b_{i}\right)}{3}=0.74
\end{aligned}
$$


となる.悲観的な人に対して $\alpha=0.8$ を仮定して， $h\left(B_{1} \mid \alpha\right), h\left(B_{2} \mid \alpha\right)$ をそれぞれ計算すると,

$$
\begin{aligned}
& h\left(B_{1} \mid \alpha\right)=1.54-0.54(2.86)^{0.8}=0.29 \\
& h\left(B_{2} \mid \alpha\right)=3.25-2.25(1.24)^{0.8}=0.58
\end{aligned}
$$

となり， $B_{2}$ を選ぶことになる.

次に，楽観的な人の場合を考える．乙のとき，価值関 数は下に凸となるので,

$$
v(x)=\left(\frac{x-1000}{5000}\right)^{2}
$$

とすると，

$$
\begin{array}{lll}
v\left(a_{1}\right)=0, & v\left(a_{2}\right)=0.64, & v\left(a_{3}\right)=1 \\
v\left(b_{1}\right)=0.04, & v\left(b_{2}\right)=0.36, & v\left(b_{3}\right)=1
\end{array}
$$

である. 焦点要素の価值の平均は

$$
\begin{aligned}
& \sum_{i=1}^{3} \frac{v\left(a_{i}\right)}{3}=0.55 \\
& \sum_{i=1}^{3} \frac{v\left(b_{i}\right)}{3}=0.47
\end{aligned}
$$

となり, $\alpha=0.2$ とすると, $h\left(B_{1} \mid \alpha\right), h\left(B_{2} \mid \alpha\right)$ は,

$$
\begin{aligned}
& h\left(B_{1} \mid \alpha\right)=3.02-2.02(1.50)^{0.2}=0.83 \\
& h\left(B_{2} \mid \alpha\right)=-1.81+2.81(0.66)^{0.2}=0.78
\end{aligned}
$$

となる。これから，意思決定者は $B_{1}$ を選ぶことにな る.

てのように，本論文で提案した「緩和された優越性の 公理」を用いることにより，悲観的な人と楽観的な人の 異なった評価を各々適切に表現することができる.

\section{6. 地球温暖化による異常気象の評価}

現在，二酸化炭素の濃度が地球上で増加しており，規 制をしないで扔くと地球が温暖化し，想像を絶する被害 が出ると考えられている ${ }^{9}$. そのため, 二酸化炭素の増 加に対して排出量を規制する必要がある. そてで, 二酸 化炭素のレベルをどのように維持するかを決定する問題 を考える.

代替案として, 次の三つを考える.

$a:$ 二酸化炭素の排出量を 2000 年までに 1990 年レベ ルに戻す.乙れによって地球温暖化の進行を防ぐ.

$b:$ 二酸化炭素の排出量を現在レベルに維持する.

$c:$ 二酸化炭素の排出量を規制しない.

また，今回は損害として異常気象にによる被害だけを 考えることにする. したがって, 属性としては, コストと 異常気象による被害の二つを対象とする. 代替案 $a, b, c$ のコストをそれぞれ $x_{1}, x_{2}, x_{3}\left(x_{1}>x_{2}>x_{3}=0\right)$ とし, 数十年後の異常気象の年間の被害確率を, 代替案 $a, b, c$ の場合に対してそれぞれ $p_{1}, \mu_{2}, \mu_{3}\left(p_{1}<\mu_{2}<\mu_{3}\right)$ であ
るとする．乙こで， $p_{1}$ は通常の Bayes 確率， $\mu_{2}, \mu_{3}$ は Dempster-Shafer の確率理論に基づく基本確率を表わ す.また，

$d_{1}$ : 地球温暖化が原因で異常気象の被害を受ける.

$d_{2}$ : 地球温暖化に関係なく異常気象の被害を受ける.

$d_{3}:$ 全く被害を受けない.

とする. 乙のとき, 三つの代替案は Table 1 のように書 ける.

Table 1 Alternatives

\begin{tabular}{|c|c|cc|}
\hline Alternative & Cost & Damage Caused by Unusual Weather \\
\hline$a$ & $x_{1}$ & $\begin{array}{c}\left\{d_{2}\right\} \\
\left\{d_{3}\right\}\end{array}$ & $\begin{array}{c}p_{1} \\
1-p_{1}\end{array}$ \\
\hline$b$ & $x_{2}$ & $\begin{array}{c}\left\{d_{1}, d_{2}\right\} \\
\left\{d_{1}, d_{2}, d_{3}\right\}\end{array}$ & $\begin{array}{c}\mu_{2} \\
1-\mu_{2}\end{array}$ \\
\hline$c$ & $x_{3}$ & $\begin{array}{c}\left\{d_{1}, d_{2}\right\} \\
\left\{d_{1}, d_{2}, d_{3}\right\}\end{array}$ & $\begin{array}{c}\mu_{3} \\
1-\mu_{3}\end{array}$ \\
\hline
\end{tabular}

代替案 $a$ における $p_{1}$ は 1990 年までの気象のデータ から得られる異常気象によって被害を受ける確率を表水 し, その残り $1-p_{1}$ が異常気象によって被害を受けない 確率を表わす. 代替案 $b$ 亿対しては異常気象の被害確 率が上がると思われるが，その確率はあいまいなすのと なる，そこで，その值を $\mu_{2}$ とし， $\mu_{2}$ を「地球温暖化が 原因で被害を受ける」,「地球温暖化に関係なく被害を受 ける」という二つの事象の集合に割り当てる．乙れによ り「地球温暖化に関係するか否かが不明であるが, 異常 気象の被害を受ける」と言う事象を $\left\{d_{1}, d_{2}\right\}$ によって表 現するてとができる. 実際, 異常気象による被害が起てっ たときに，それが地球温暖化が原因なのか，そうでない のかがわからない，それが地球温暖化が原因と考える人 あいれば，そうでないと考える人むいるであろう．ての ような不確実状況下を適切に表わせるように，てのよう な割り当てを行うのである. そして, 残りの確率 $1-\mu_{2}$ をすべての事象に割り当てる. 代替案 $c$ についてあ代替 案 $b$ と同じょうに割り当てる.

Dempster-Shafer の確率理論を導入した不確実下の 価值関数を用いて先に述べた三つの代替案を評価する. この場合 2 属性であるので,

$$
\begin{aligned}
F^{*}(a)= & f^{*}\left(x_{1},\left\{d_{2}\right\}, p_{1}\right)+f^{*}\left(x_{1},\left\{d_{3}\right\}, p_{1}\right) \\
F^{*}(b)= & f^{*}\left(x_{2},\left\{d_{1}, d_{2}\right\}, \mu_{2}\right) \\
& +f^{*}\left(x_{2},\left\{d_{1}, d_{2}, d_{3}\right\}, 1-\mu_{2}\right) \\
F^{*}(c)= & f^{*}\left(x_{3},\left\{d_{1}, d_{2}\right\}, \mu_{3}\right) \\
& +f^{*}\left(x_{3},\left\{d_{1}, d_{2}, d_{3}\right\}, 1-\mu_{3}\right)
\end{aligned}
$$

となり,さらに，2 属性間に危険選好差独立性が成立す ると仮定すると， 


$$
\begin{aligned}
F^{*}(a)= & f^{*}\left(x_{1}^{R},\left\{d_{2}\right\}, p_{1}\right)+f^{*}\left(x_{1},\left\{d_{2}\right\}^{R}, p_{1}\right) \\
& +f^{*}\left(x_{1}^{R},\left\{d_{3}\right\}, 1-p_{1}\right) \\
& +f^{*}\left(x_{1},\left\{d_{3}\right\}^{R}, 1-p_{1}\right) \\
F^{*}(b)= & f^{*}\left(x_{2}^{R},\left\{d_{1}, d_{2}\right\}, \mu_{2}\right) \\
& +f^{*}\left(x_{2},\left\{d_{1}, d_{2}\right\}^{R}, \mu_{2}\right) \\
& +f^{*}\left(x_{2}^{R},\left\{d_{1}, d_{2}, d_{3}\right\}, 1-\mu_{2}\right) \\
& +f^{*}\left(x_{2},\left\{d_{1}, d_{2}, d_{3}\right\}^{R}, 1-\mu_{2}\right) \\
F^{*}(c)= & f^{*}\left(x_{3}^{R},\left\{d_{1}, d_{2}\right\}, \mu_{3}\right) \\
& +f^{*}\left(x_{3},\left\{d_{1}, d_{2}\right\}^{R}, \mu_{3}\right) \\
& +f^{*}\left(x_{3}^{R},\left\{d_{1}, d_{2}, d_{3}\right\}, 1-\mu_{3}\right) \\
& +f^{*}\left(x_{3},\left\{d_{1}, d_{2}, d_{3}\right\}^{R}, 1-\mu_{3}\right)
\end{aligned}
$$

となる。

さらに，コストの価値関数を $v_{1}\left(x_{i}\right)$, 異常気象による 被害に対する結果の要素の価值を $v_{2}\left(d_{i}\right)$, その部分集合 の価值を $h(B \mid \alpha)$ とし，異常気象による被害確率に関 する価值関数を $w(p)$ と扔く．また，コストと異常気象 による被害に対するスケール定数をそれぞれ $k_{1}, k_{2}$ とお <.

$$
\begin{aligned}
& \text { これらを }(28) \sim(30) \text { 式に代入すると, } \\
& \qquad \begin{aligned}
F^{*}(a)= & k_{1} w\left(p_{1}\right) v_{1}\left(x_{1}\right)+k_{2} w\left(p_{1}\right) v_{2}\left(d_{2}\right) \\
& +k_{1} w\left(1-p_{1}\right) v_{1}\left(x_{1}\right) \\
& +k_{2} w\left(1-p_{1}\right) v_{2}\left(d_{3}\right)
\end{aligned}
\end{aligned}
$$

$F^{*}(b)=k_{1} w\left(\mu_{2}\right) v_{1}\left(x_{2}\right)+k_{2} w\left(\mu_{2}\right) h\left(\left\{d_{1}, d_{2}\right\} \mid \alpha\right)$

$$
\begin{aligned}
& +k_{1} w\left(1-\mu_{2}\right) v_{1}\left(x_{2}\right) \\
& +k_{2} w\left(1-\mu_{2}\right) h\left(\left\{d_{1}, d_{2}, d_{3}\right\} \mid \alpha\right)
\end{aligned}
$$

$F^{*}(c)=k_{1} w\left(\mu_{3}\right) v_{1}\left(x_{3}\right)+k_{2} w\left(\mu_{3}\right) h\left(\left\{d_{1}, d_{2}\right\} \mid \alpha\right)$

$$
\begin{aligned}
& +k_{1} w\left(1-\mu_{3}\right) v_{1}\left(x_{3}\right) \\
& +k_{2} w\left(1-\mu_{3}\right) h\left(\left\{d_{1}, d_{2}, d_{3}\right\} \mid \alpha\right)
\end{aligned}
$$

が得られ，乙れらを評価する．ただし，値が大きくなる ほど不効用が高いものとする．まず，乙の方法で適切に 評価できるか否かを調べるために，次のような值を仮定 する.

$$
\begin{array}{lll}
v_{1}\left(x_{1}\right)=1, & v_{1}\left(x_{2}\right)=0.3, & v_{1}\left(x_{3}\right)=0 \\
w\left(p_{1}\right)=0, & w\left(\mu_{2}\right)=0.3, & w\left(\mu_{3}\right)=1 \\
w(p)=1 & \left(p \geq \mu_{3}\right) & \\
v_{2}\left(d_{1}\right)=1, & v_{2}\left(d_{3}\right)=0
\end{array}
$$

てれらの意味は，コストに関しては三つの代替案の最も 良い場合（コストがかからない場合）を0，悪い場合を 1 とし, 現状を維持するコストはそれほどかからないと 仮定してててでは仮に 0.3 とした。確率に関してあ最す 良い場合を 0 , 最む悪い場合（何むしない）を 1 とし，現 状を維持した場合は 1990 年レベルと大差はないと考え えてててでは仮に 0.3 とした. また， $\mu_{3}$ よりも確率が大 きい場合は 1 とした，また，被害に関する結果も最良の
結果を 0 , 最悪の結果を 1 とした. こてでは, 本論文に 示したモデルが，様々な人々の価值観を表わす記述的モ デルとして適切か否かを検証するために，0.3などの值 を仮定して議論しているが，現実の意思決定支援を目的 とした規範的モデルとして使う場合には，0.3 な゙の值 の設定については感度分析などによって更に検討を加え る必要がある。

このとき, (31)〜 (33) 式の評価式は,

$$
\begin{aligned}
F^{*}(a)= & k_{1} \times 0 \times 1+k_{2} \times 0 \times v_{2}\left(d_{2}\right) \\
& +k_{1} \times 1 \times 1+k_{2} \times 1 \times 0 \\
= & k_{1} \\
F^{*}(b)= & k_{1} \times 0.3 \times 0.3+k_{2} \times 0.3 \times h\left(\left\{d_{1}, d_{2}\right\} \mid \alpha\right) \\
& +k_{1} \times 1 \times 0.3 \\
& +k_{2} \times 1 \times h\left(\left\{d_{1}, d_{2}, d_{3}\right\} \mid \alpha\right) \\
= & 0.39 k_{1}+k_{2}\left\{0.3 h\left(\left\{d_{1}, d_{2}\right\} \mid \alpha\right)\right. \\
& \left.+h\left(\left\{d_{1}, d_{2}, d_{3}\right\} \mid \alpha\right)\right\} \\
F^{*}(c)= & k_{1} \times 1 \times 0+k_{2} \times 1 \times h\left(\left\{d_{1}, d_{2}\right\} \mid \alpha\right) \\
& +k_{1} \times 1 \times 0 \\
& +k_{2} \times 1 \times h\left(\left\{d_{1}, d_{2}, d_{3}\right\} \mid \alpha\right) \\
= & k_{2}\left\{h\left(\left\{d_{1}, d_{2}\right\} \mid \alpha\right)\right. \\
& \left.+h\left(\left\{d_{1}, d_{2}, d_{3}\right\} \mid \alpha\right)\right\}
\end{aligned}
$$

となる。ささらに，どのような人にとっても，地球温暖化 に関係なく被害を受けるととに対する不効用は，全く被 害を受けないときの不効用と大差はないと考えて,

$$
v_{2}\left(d_{2}\right)=0.1
$$

とする. 悲観係数を導入して焦点要素の不効用を評価す ると,

$$
\begin{aligned}
h\left(\left\{d_{1}, d_{2}\right\} \mid \alpha\right)= & \alpha\left(d_{2}, d_{3}\right) v_{2}\left(d_{1}\right) \\
& +\left(1-\alpha\left(d_{1}, d_{2}\right)\right) v_{2}\left(d_{2}\right) \\
= & 0.9 \alpha\left(d_{1}, d_{2}\right)+0.1 \\
h\left(\left\{\left(d_{1}, d_{2}, d_{3}\right\} \mid \alpha\right)=\right. & -0.53+0.53(2.89)^{\alpha}
\end{aligned}
$$

となり，(38) 式を(35),（36) 式に代入すると（34） (36) 式は,

$$
\begin{aligned}
F^{*}(a)= & k_{1} \\
F^{*}(b)= & 0.39 k_{1}+k_{2}\left\{0.27 \alpha\left(d_{1}, d_{2}\right)+0.03\right. \\
& \left.+h\left(\left\{d_{1}, d_{2}, d_{3}\right\} \mid \alpha\right)\right\} \\
F^{*}(c)= & k_{2}\left\{0.9 \alpha\left(d_{1}, d_{2}\right)+0.1\right. \\
& \left.+h\left(\left\{d_{1}, d_{2}, d_{3}\right\} \mid \alpha\right)\right\}
\end{aligned}
$$

となる. 乙れらを用いて悲観的な人，普通の人，楽観的 な人の評価を適切に表現できるか否かを調べる．その前 に，各々のタイプの人が地球温暖化に対してどのように 感じるかを述べる．悲観的な人は「温暖化は非常に深刻 で，温暖化の進行は非可逆的で，一度はずみがつくと進 
行の一途をたどる」と考える人である．普通の人は， 「温暖化は深刻で温暖化の進行がこのまま進めば 21 世紀 半ばに気温が数度上昇する」と考える人である．乙こで は，温暖化の進行が非可逆とまでは考えていない点が， 「非常に深刻」とは考えていないゆえんである．楽観的 な人はさほど深刻ではなく，「温暖化は地球の気候変動 より小さい，または，科学技術の進歩で解決できる」と 考える人である.

\section{・悲観的な人}

悲観的な人ほど $\alpha$ は大きくなるので,

$$
\alpha\left(d_{1}, d_{2}\right)=\alpha\left(d_{1}, d_{3}\right)=0.8
$$

とすると,

$$
h\left(\left\{d_{1}, d_{2}, d_{3}\right\} \mid 0.8\right)=0.71
$$

を得る.これらを評価式に代入して,

$$
\begin{aligned}
& F^{*}(a)=k_{1} \\
& F^{*}(b)=0.39 k_{1}+0.96 k_{2} \\
& F^{*}(c)=1.53 k_{2}
\end{aligned}
$$

となる。

\section{・普通の人}

$$
\alpha\left(d_{1}, d_{2}\right)=\alpha\left(d_{1}, d_{3}\right)=0.5
$$

とすると,

$$
h\left(\left\{d_{1}, d_{2}, d_{3}\right\} \mid 0.5\right)=0.37
$$

を得る.これらを評価式に代入して，

$$
\begin{aligned}
& F^{*}(a)=k_{1} \\
& F^{*}(b)=0.39 k_{1}+0.54 k_{2} \\
& F^{*}(c)=0.92 k_{2}
\end{aligned}
$$

となる。

\section{・楽観的な人}

$$
\alpha\left(d_{1}, d_{2}\right)=\alpha\left(d_{1}, d_{3}\right)=0.2
$$

とすると

$$
h\left(\left\{d_{1}, d_{2}, d_{3}\right\} \mid 0.2\right)=0.13
$$

を得る.これらを評価式に代入して，

$$
\begin{aligned}
& F^{*}(a)=k_{1} \\
& F^{*}(b)=0.39 k_{1}+0.21 k_{2} \\
& F^{*}(c)=0.41 k_{2}
\end{aligned}
$$

となる。

これらの結果をまとめると Table 2 のようになる.

さらに，スケール定数を変化させてみると Table 3 の ようになる.乙こで, 表中太字は三つの代替案 $a, b, c$ の中で最も好ましいものに対応している.

この表を見ると悲観的な人（ $\alpha$ が 1 に近い人）ほど同
Table 2 Evaluation of alternatives by various type of persons

\begin{tabular}{|c|c|c|c|}
\hline Alternative & $a$ & $b$ & $c$ \\
\hline Pessimistic person & $k_{1}$ & $0.39 k_{1}+0.96 k_{2}$ & $1.53 k_{2}$ \\
\hline Ordinary person & $k_{1}$ & $0.39 k_{1}+0.54 k_{2}$ & $0.92 k_{2}$ \\
\hline Optimistic person & $k_{1}$ & $0.39 k_{1}+0.21 k_{2}$ & $0.41 k_{2}$ \\
\hline
\end{tabular}

Table 3 Evaluated values for various scaling coefficients

\begin{tabular}{|c|c|c|c|c|c|c|c|c|c|c|}
\hline \multirow{2}{*}{$k_{1}$} & \multirow{2}{*}{$k_{2}$} & \multicolumn{3}{|c|}{$\alpha=0.8$} & \multicolumn{3}{c|}{$\alpha=0.5$} & \multicolumn{3}{c|}{$\alpha=0.2$} \\
\cline { 3 - 10 } & & $a$ & $b$ & $c$ & $a$ & $b$ & $c$ & $a$ & $b$ & $c$ \\
\hline 0.0 & 1.0 & $\mathbf{0 . 0 0}$ & 0.96 & 1.53 & $\mathbf{0 . 0 0}$ & 0.54 & 0.92 & $\mathbf{0 . 0 0}$ & 0.21 & 0.41 \\
\hline 0.1 & 0.9 & $\mathbf{0 . 1 0}$ & 0.90 & 1.38 & $\mathbf{0 . 1 0}$ & 0.53 & 0.83 & $\mathbf{0 . 1 0}$ & 0.23 & 0.37 \\
\hline 0.2 & 0.8 & $\mathbf{0 . 2 0}$ & 0.85 & 1.22 & $\mathbf{0 . 2 0}$ & 0.51 & 0.74 & $\mathbf{0 . 2 0}$ & 0.25 & 0.33 \\
\hline 0.3 & 0.7 & $\mathbf{0 . 3 0}$ & 0.79 & 1.07 & $\mathbf{0 . 3 0}$ & 0.50 & 0.64 & 0.30 & $\mathbf{0 . 2 6}$ & 0.29 \\
\hline 0.4 & 0.6 & $\mathbf{0 . 4 0}$ & 0.73 & 0.92 & $\mathbf{0 . 4 0}$ & 0.48 & 0.55 & 0.40 & 0.28 & $\mathbf{0 . 2 5}$ \\
\hline 0.5 & 0.5 & $\mathbf{0 . 5 0}$ & 0.67 & 0.76 & 0.50 & 0.46 & $\mathbf{0 . 4 6}$ & 0.50 & 0.30 & $\mathbf{0 . 2 1}$ \\
\hline 0.6 & 0.4 & $\mathbf{0 . 6 0}$ & 0.62 & 0.61 & 0.60 & 0.45 & $\mathbf{0 . 3 7}$ & 0.60 & 0.32 & $\mathbf{0 . 1 6}$ \\
\hline 0.7 & 0.3 & 0.70 & 0.56 & $\mathbf{0 . 4 6}$ & 0.70 & 0.44 & $\mathbf{0 . 2 8}$ & 0.70 & 0.34 & $\mathbf{0 . 1 2}$ \\
\hline 0.8 & 0.2 & 0.80 & 0.50 & $\mathbf{0 . 3 1}$ & 0.80 & 0.42 & $\mathbf{0 . 1 8}$ & 0.80 & 0.35 & $\mathbf{0 . 0 8}$ \\
\hline 0.9 & 0.1 & 0.90 & 0.45 & $\mathbf{0 . 1 5}$ & 0.90 & 0.41 & $\mathbf{0 . 0 9}$ & 0.90 & 0.37 & $\mathbf{0 . 0 4}$ \\
\hline 1.0 & 0.0 & 1.00 & 0.39 & $\mathbf{0 . 0 0}$ & 1.00 & 0.39 & $\mathbf{0 . 0 0}$ & 1.00 & 0.39 & $\mathbf{0 . 0 0}$ \\
\hline
\end{tabular}

じスケール定数でも代替案 $a$ を選択している.すなわち, コストがかかってもかまわないから，二酸化炭素の排出 量レベルを低くすべきであるということが表わせている. 逆に，楽観的な人ほど排出量に関しては規制をしないと いう代替案を選ぶということが適切に評価されているこ とがわかる。

\section{7. おわりに}

本論文では，Dempster-Shafer の確率理論を導入し た不確実下の価値関数を構成するにあたって，新たな優 越性の公理を提案し，乙れに基づいて価值関数を構成す る方法を示した．まず焦点要素のすべての要素を評価の 対象にするために，焦点要素のすべての要素の価值の平 均之いうものを考えた。 そして，乙の平均を従来モデル に導入した.

つぎに，「人が焦点要素の価值を判断するとき，普通 の人は焦点要素に含まれるすべての要素の価值の平均が その焦点要素の価值であると感じる」，「悲観的な人は焦 点要素のすべての要素の価值の平均よりも低く, 楽観的 な人は平均よりも高く感じる」ということを仮定した。 この仮定により，最良の要素之最悪の要素から得られる 悲観係数, 最良の要素, 最悪の要素, 平均の四つを用い 
て焦点要素の価值を決定できるように, 新たに「緩和さ れた優越性の公理」を提案した. ての公理従って決め られる焦点要素の価值に基づいて不確実下の価値関数を 構成し，代替案を評価する方法を示した。

優越性を緩和したモデルを用いて地球の温暖化に関わ りの深い二酸化炭素排出量規制に関するいくつかの代替 案の評価を試みた. 一般に, 異常気象が起とったときに それが地球温暖化が原因であるのか，そうでないのかが 明らかでない。乙てに, Dempster-Shafer の確率理論 を用い,「地球温暖化が原因である」,「原因でない」と いう複数の要素加成る焦点要素に基本確率を割り当て ることによって，乙のような不確実下の価值評価に対処 することができた。

今回の方法は不確実下の価值関数に Dempster-Shafer の確率理論を導入したが, 不確実下の価值関数は特定条 件の屯とで期待効用理論やプロスペクト理論4), 10) 亿縮退 できるので, 期待効用理論やプロスペクト理論による評 価法にも同様の過程で Dempster-Shafer の確率理論 を導入することができる. また, 本モデルは, 焦点要素 が単一要素になった場合は不確実下の価值関数に縮退す る. そのため, 不確実下の価值関数によって評価できる 現象はすべて評価できるととになる.

今後の課題としては,

（1）評価モデルに Dempster-Shafer の確率理論を用 いるときに基本確率を割り当てる必要があるが, その割り当て方についてさらに研究を進める.

（2）本論文では，焦点要素の価值を求めるにあたり, すべての要素の価伹の相加平均を考えたが, 相乗 平均など別のあのを用いて本モデルと比較する. などを挙げることができる.

本研究は, 文部省科学研究費重点領域研究「人間地 球系」No.05278233 のもとで実施されたととを付記す る.

\section{参 考 文 献}

1) J. von Neumann and O. Morgensten : Theory of Games and Economic Behavior, Ed. 2, Princeton University Press (1947)

2) M. Allais and O. Hagen : Expected Utility Hypothesis and the Allais Paradox, Reidel (1979)

3) J.C. Hershey, H.C. Kunreuther and P. J. H. Schoemaker : Sources of Bias in Assessment Procedures for Utility Function; Management Science, Vol. 28, No. 8, pp. 936 954 (1982)

4) D. Kahneman and A. Tversky : Prospect Theory : An Analysis of Decision under Risk; Econometrica, Vol. 47, No. 3, pp. 263 291 (1979)

5) 田村, 森, 中村: 不確実性を考虑した価值関数による選好 のモデル化; 計測自動制御学会論文集, Vol. 23, No. 1, pp. $54 \sim 59$ (1987)
6) D. Ellsberg : Risk, Ambiguity and the Savage Axioms ; Quarterly Journal of Economics, Vol. 75, No. 4, pp. 643 669 (1961)

7) G. Shafer : A Mathematical Theory of Evidence, Princeton Univ. Press (1976)

8) 田村, 小林, 鳩野 : Dempster-Shafer の確率理論を導入し た不確実下の価值関数; システム制御情報学会論文誌, Vol. 4, No. 4, pp. 133 139 (1991)

9) 山元 : 地球異常, 集英社 (1993)

10) D. N. Jackson and R. K. Sarin : Prospect Versus Utility ; Management Science, Vol. 35, No. 1, pp. 22 41 (1989) 
